\title{
Risk Governance And Performance: Research On Indonesian And Malaysian Banking
}

\author{
MOULDY MEIRINE* \\ ETIKA KARYANI
}

STIE Indonesia Banking School

\begin{abstract}
The purpose of this research is to investigate the risk governance associated with bank performance in Indonesia and Malaysia from 2010 to 2014. The risk governance variables used in this study are board size, board meeting, risk committee size, and risk committee meeting. Moreover, the selected sample is using purposive sampling method. Using return on asset (ROA) and Tobin's $Q$ to measure the bank performance, this study proved that risk governance has a positive relationship with return on an asset in Indonesia. These results support the FSB (2013) recommendation on improving the risk governance framework. Special supervision of risk needs to be taken to prevent risks that may occur in the bank's activities. However, this finding also revealed that the more risk committee meetings, the more the value of the company will reduce. The number of risk committee meeting which was held too often on Indonesian banks, actually provide less effective results. Therefore it is lowering the price of bank shares. Meanwhile, the results show the amount of risk in the banking committee meetings in Malaysia have a positive effect on ROA, and the number of risk committees has a positive effect on firm value.
\end{abstract}

Keywords: Risk Governance, Risk Committee, Return on Asset, Tobin's $Q$

Intisari: Tujuan penelitian ini adalah untuk menyelidiki tata kelola risiko yang terkait dengan kinerja bank di Indonesia dan Malaysia selama periode 2010-2014. Variabelvariabel tata kelola risiko yang digunakan dalam penelitian ini adalah ukuran dewan, rapat dewan, ukuran komite risiko, dan rapat komite risiko. Selain itu, sampel yang dipilih menggunakan metode purposive sampling. Menggunakan laba atas aset (ROA) dan Tobin's $Q$ untuk mengukur kinerja bank, penelitian ini membuktikan bahwa tata kelola risiko memiliki hubungan yang positif dengan return on asset di Indonesia. Hasil ini mendukung rekomendasi FSB (2013) untuk meningkatkan kerangka kerja tata kelola risiko. Pengawasan khusus terhadap risiko harus diambil untuk mencegah risiko yang mungkin terjadi dalam kegiatan bank. Namun, temuan ini juga mengungkapkan bahwa semakin banyak komite risiko semakin banyak nilai perusahaan akan berkurang. Jumlah rapat komite risiko yang terlalu sering diadakan di bank-bank Indonesia, sebenarnya memberikan hasil yang kurang efektif, oleh karena itu menurunkan harga saham bank. Sementara itu, hasil menunjukkan jumlah risiko dalam rapat komite perbankan di Malaysia memiliki efek positif pada ROA dan jumlah komite risiko memiliki efek positif pada nilai perusahaan. 
Kata Kunci: Tata Kelola Risiko, Komite Risiko, Pengembalian Aset, Tobin $Q$

\section{Introduction}

The financial crisis that occurred in 2008 turned out to have affected global finance (Sudarsono, 2009). The one that triggers this economic crisis is the failure of banks-corporate governance and financial institutions. The failure is due to some directors lack of experience in the financial industry and less attention to the risk management. The members of the risk committee also have lack of experience in risk management $\left(\mathrm{FSB}^{1}, 2013\right)$.

This global financial crisis impacted the Asian region in the form of declining economic growth and the occurrence of financial difficulties in some banks or financial institutions (Sudarsono, 2009). One of the countries affected by the crisis in Indonesia (Bank Indonesia, 2010). The crisis occurred as a result of excessive risk taken by banks and lack of experience of directors regarding the financial industry and its complexity (Bank Indonesia, 2009). The global crisis also affected the Malaysian economic system in the third quarter of 2008 and continued into the first quarter of 2009. However, a robust financial system and comprehensive policy implementation prevent the Malaysian state from a prolonged bad economy (Bank Negara Malaysia, 2009).

Based on the impact of the crisis that occurred in 2007-2008, the FSB evaluates the oversight of risk governance in financial institutions in several countries. The FSB groups the evaluation object into three parts: (i) all surveyed firms; (ii) firms identified by the FSB and Basel Committee on Banking Supervision (BCBS) as global systemically that is important for the financial institutions, or G-SIFIs ${ }^{2}$; and (iii) firms

\footnotetext{
${ }^{1}$ Financial Stability Board is an international body that monitors and makes recommendations about the global financial system.

${ }^{2}$ Global systemically critical financial institutions, 17 financial institutions identified by FSB and BCBS (FSB 2013).
} 
that reside in advanced economies or emerging market and developing economies $\left(\right.$ EMDEs $\left.^{3}\right)$. The results show that almost 50 percent of surveyed banks do not meet all the evaluation criteria ${ }^{4}$ (FSB, 2013). Due to a large number of financial institutions that do not meet the evaluation criteria, the FSB sets out some recommendations to improve the risk of the governance framework.

Studies on risk governance which mainly focus on banking performance are still limited. Most of the previous studies focus on corporate governance and its relationship with banking performance (Sari, 2010). Many empirical kinds of literature stated that banks with proper governance mechanisms generally have better financial performance, higher corporate values and higher stock returns (Battaglia and Gallo 2015). Laeven and Levine's research (2009), which focus on conflicts between bank managers and owners, suggest that risk-taking by banks is a variation of shareholders comparative strength in the corporate governance structure of banks. Also, they stated that the relationship between banking risk and capital regulations, deposit insurance policies, and restrictions on bank activity depend heavily on the ownership structure of each bank. Binh and Tam's research (2014) proved that there are differences effect of corporate governance proxies on bank performance between Vietnam and Malaysia. Sari's research (2010) which measures corporate governance with its monitoring mechanisms shows that there is a negative relationship between monitoring mechanisms of internal control and banking performance.

Some researchers examined the effect of risk governance on banking performance during the 2007-2008 global crisis; examples Aebi, Sabato, and Schmid (2012) and Battaglia and Gallo (2015). Aebi, Sabato, and Schmid (2012) analyze the effect of risk

\footnotetext{
${ }^{3}$ Emerging market and developing economies, classification of advanced and developing countries based on World Bank World Development Indicators (FSB, 2013).

${ }^{4}$ Evaluation criteria set by FSB about firm's approach toward risk governance, board responsibilities and practices, risk management function, and independent assessment of risk governance framework. See Thematic Review on Risk Governance (FSB 2013).
} 
governance on banking performance in North America. They found that banks with better risk management structures performed better. Further research by Battaglia and Gallo (2015) examined risk governance in banking performance in China and India. The results show that risk governance has a positive effect on banking performance in both countries.

The importance of risk governance and the limited research related to risk governance and banking performance are factors that motivate us to examine the effect of risk governance on banking performance on the scope of ASEAN. The ASEAN countries to be sampled are Indonesia and Malaysia. Existing researchers, namely Battaglia and Gallo (2015) focus on the countries of India and China. While previous researchers had never researched in Indonesia and Malaysia.

The selection of Indonesia and Malaysia as the samples is mainly because the two countries have differences in the governance structure. Indonesia uses two-tier system, while Malaysia uses the one-tier system. Also, these two countries as ASEAN member countries face the ASEAN Economic Community ${ }^{6}$ (AEC). The implementation of AEC may be constrained by the weak governance in ASEAN countries (Chia, 2013). This makes ASEAN countries should implement good governance to compete with other countries.

\section{Theoretical Framework and Hypothesis Development}

\subsection{Agency theory}

Agency theory is a contract under which one or more persons (the principal(s)) engage another person (the agent) to perform some service on their behalf which involves delegating some decision-making authority to the agent (Jensen and

\footnotetext{
5 system governance structure where the supervisory function of the board is performed by a separate entity known as a supervisory board, which has no executive functions, while in one tier system the board has a broader role. (FSB, 2013).

${ }^{6}$ ASEAN Economic Community or AEC is the economic integration of free trade among ASEAN countries (ASEAN, 2015).
} 
Meckling, 1976). The relationship between shareholders and management arises because shareholders or owners do not have the skills to manage their own company. The limited ability of shareholders to oversee management activities can lead the manager behavior to improve their own wellbeing. If this condition occurs, there will be a conflict between agents and principals called agency problems (Taswan, 2010: 114-115). The agency problem occurs because of differences information between shareholders and bank managers, which is called asymmetric information.

The company can reduce the agency problem by applying corporate governance. Following one of the good governance principles that are transparency, management must transparently disclose information so that the owners know the information that is obtained only by the managers (KNKG, 2006). Moreover, the company owners consider that the management tends to not to avoid the risks at the time of decision making (Hendriksen and Van Breda, 2002: 221). Therefore by using the same principle, risk governance can also reduce agency problems by making transparent disclosures regarding risks.

The implementation of good corporate governance can improve banks performance in long-term and can compete well in global business (Windah and Andono, 2013). Investors also tend to avoid banks that do not implement good governance. Investors believe the companies that implement good corporate governance have tried to minimize the risks of self-profitable decisions, thereby enhancing performance that can maximize corporate value (Windah and Andono, 2013).

\subsection{Signaling Theory}

Signaling theory explains the reasons why the company has an incentive to provide financial statements to external parties. The impulse arises because there is asymmetric information between the company and the outsiders. The company knows more information and prospects compared to outside parties such as investors and creditors (Simanungkalit, 2009, in Susilowati and Turyanto, 2011). To reduce 
asymmetric information, the company must disclose both financial and non-financial information (Retno, 2012).

Signals received by external parties will be a consideration in determining decisions. The existence of a board or commissioner in a bank can assist managers in delivering signals to external parties. The board or commissioner may exercise oversight and make decisions in determining which reports can be submitted. Also, banks should disclose any risks associated with bank activities. The bank risk committee function is to manage the existing risks so that the risk does not give a negative value to external parties.

\subsection{Risk governance}

Risk governance applies the principles of good governance to the identification, assessment, management, and communication of risks (IRGC, 2015). Risk governance focuses on the risks that exist in the company. Risk governance has a framework through which the board and management establish the firm's strategy; articulate and monitor adherence to risk appetite and risk limits; and identify, measure and manage risks. (FSB, 2013 and BCBS 2015). The following Table 1 explains the differences between corporate governance and risk governance:

Table 1

Differences between Risk Governance and Corporate Governance

\begin{tabular}{|c|c|c|}
\hline & Corporate Governance & Risk Governance \\
\hline Definition & $\begin{array}{l}\text { "A set of relationships between a } \\
\text { company's management, its board, its } \\
\text { shareholders and other stakeholders } \\
\text { which provides the structure through } \\
\text { which the objectives of the company } \\
\text { are set, and the means of attaining } \\
\text { those objectives and monitoring } \\
\text { performance." (BCBS, 2015) }\end{array}$ & $\begin{array}{l}\text { "The principles of good governance } \\
\text { to the identification, assessment, } \\
\text { management, and communication of } \\
\text { risks" (IRGC, 2015) }\end{array}$ \\
\hline $\begin{array}{l}\text { Responsible } \\
\text { party }\end{array}$ & Board & Board and risk committee \\
\hline Principles & $\begin{array}{l}\text { 1. Board members should be qualified } \\
\text { for their positions, have a clear } \\
\text { understanding of their role in } \\
\text { corporate governance and be able to } \\
\text { exercise sound judgment about the }\end{array}$ & $\begin{array}{l}\text { The board has overall } \\
\text { responsibility for the bank, } \\
\text { including approving and } \\
\text { overseeing management's } \\
\text { implementation of the bank's }\end{array}$ \\
\hline
\end{tabular}




\begin{tabular}{|c|c|}
\hline $\begin{array}{l}\text { affairs of the bank. } \\
\text { 2. The board of directors should } \\
\text { approve and oversee the bank's } \\
\text { strategic objectives and corporate } \\
\text { values. } \\
\text { 3. The board of directors should set } \\
\text { and enforce clear lines of } \\
\text { responsibility and accountability } \\
\text { throughout the organization. } \\
\text { 4. The board should ensure that there } \\
\text { is an appropriate oversight by senior } \\
\text { management consistent with board } \\
\text { policy. } \\
\text { 5. The board and senior management } \\
\text { should effectively utilize the work } \\
\text { conducted by the internal audit } \\
\text { function, external auditors, and } \\
\text { internal control functions. } \\
\text { 6. The board should ensure that } \\
\text { compensation policies and practices } \\
\text { are consistent with the bank's } \\
\text { corporate culture, long-term } \\
\text { objectives and strategy, and control } \\
\text { environment. } \\
\text { 7. The bank should be governed } \\
\text { transparently. } \\
\text { 8. The board and senior management } \\
\text { should understand the bank's } \\
\text { operational structure. }\end{array}$ & $\begin{array}{l}\text { strategic objectives, governance } \\
\text { framework, and corporate culture. } \\
\text { 2. Board members should be and } \\
\text { remain qualified, individually and } \\
\text { collectively, for their positions. } \\
\text { They should understand their } \\
\text { oversight and corporate } \\
\text { governance role and be able to } \\
\text { exercise sound, objective } \\
\text { judgment about the affairs of the } \\
\text { bank. } \\
\text { 3. The board should define } \\
\text { appropriate governance structures } \\
\text { and practices for its own work. } \\
\text { 4. Senior management should carry } \\
\text { out and manage the bank's } \\
\text { activities in a manner consistent } \\
\text { with the business strategy, risk } \\
\text { appetite, remuneration, and other } \\
\text { policies. } \\
\text { 5. The board of the parent company } \\
\text { has the overall responsibility for } \\
\text { the group and for ensuring the } \\
\text { establishment and operation of a } \\
\text { clear governance framework. } \\
\text { 6. Banks should have an effective } \\
\text { independent risk management } \\
\text { function. } \\
\text { 7. Risks should be identified, } \\
\text { monitored and controlled on an } \\
\text { ongoing bank-wide. } \\
\text { 8. An effective risk governance } \\
\text { framework requires robust } \\
\text { should support sound corporate } \\
\text { abommunication within the bank } \\
\text { about risk. } \\
\text { 9. The bank's board of directors is } \\
\text { responsible for overseeing the } \\
\text { management of the bank's } \\
\text { compliance risk. } \\
\text { 10. The internal audit function should } \\
\text { provide independent assurance to } \\
\text { the board and should support } \\
\text { poand senior management in } \\
\text { fhe bank's remuneration structure }\end{array}$ \\
\hline
\end{tabular}




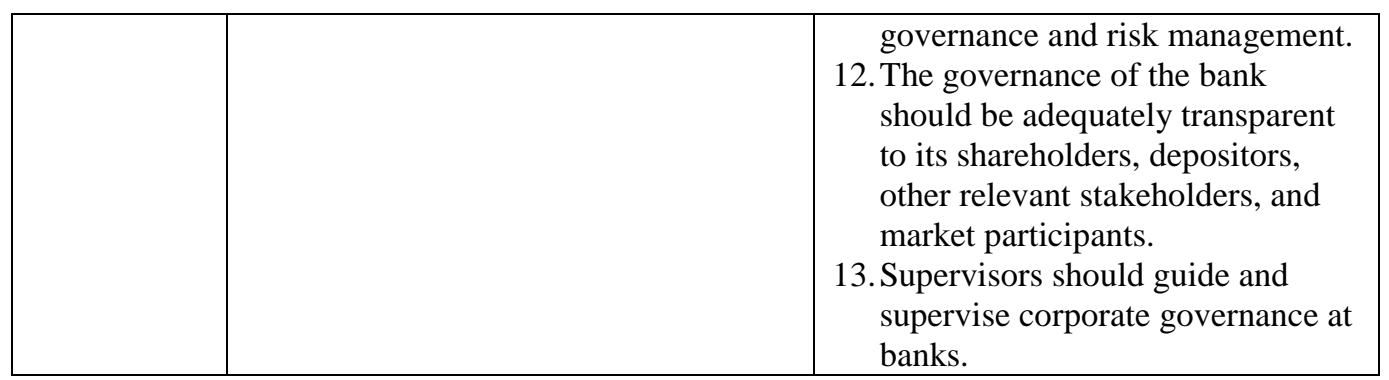

Sources: BCBS 2006, BCBS 2015, and IRGC 2015

The FSB has also issued an example of an effective risk governance framework for the company. Figure 1 is an example of a risk governance framework along with an explanation of the roles and responsibilities of the board, the risk management function, and the independent assessment of the risk governance framework:

Figure 1

Example of Risk Governance Framework

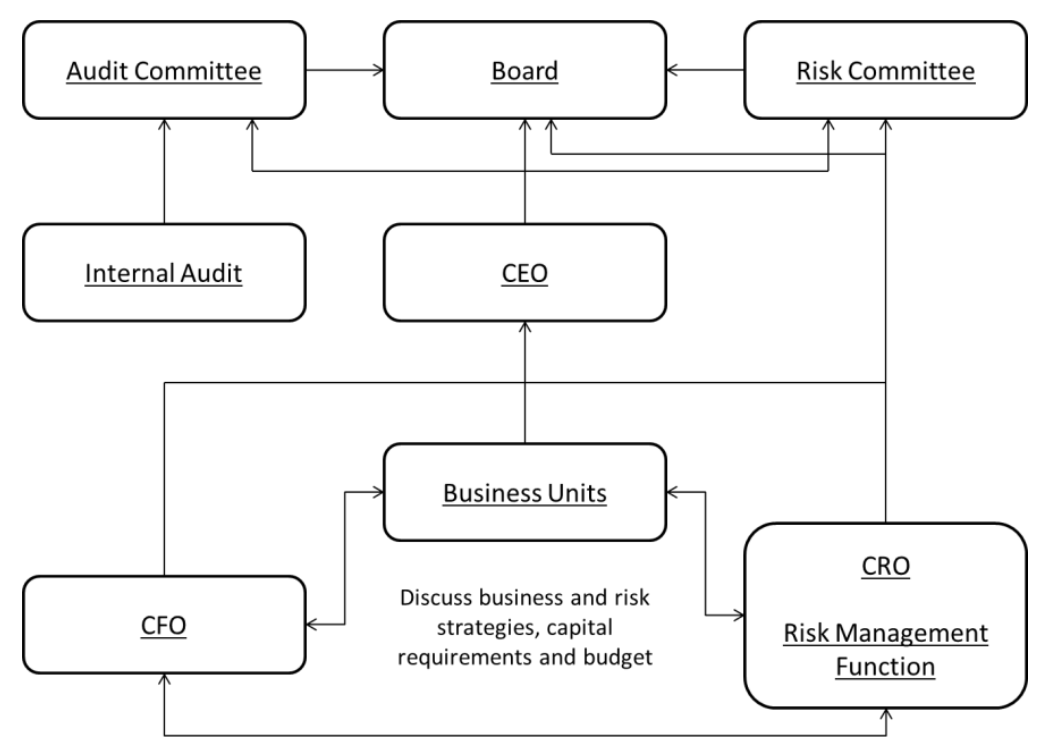

Source: FSB, 2013

1. Board: The board is responsible for ensuring that the firm has an appropriate risk governance framework given by the firm's business model, complexity and size which is embedded in the firm's risk culture. 
2. Firm-wide risk management function: The $\mathrm{CRO}$ and risk management function are responsible for the firm's risk management across the entire organization, ensuring that the firm's risk profile remains within the risk appetite statement (RAS) as approved by the board. The risk management function is responsible for identifying, measuring, monitoring, and recommending strategies to control or mitigate risks, and reporting on risk exposures on an aggregated and disaggregated basis.

3. Independent assessment of the risk governance framework: The independent evaluation of the firm's risk governance framework plays a crucial role in the ongoing maintenance of a firm's internal controls, risk management, and risk governance. It helps a firm accomplish its objectives by bringing a disciplined approach to evaluate and improve the effectiveness of risk management, control, and governance processes. This may involve internal parties, such as internal audit, or external resources such as third-party reviewers (e.g., audit firms, consultants) (FSB, 2013).

\subsection{Banking performance}

Performance refers to how adequately a financial firm meets the needs of its stockholders (owners), employees, depositors, and other creditors, and borrowing customers (Rose dan Hudgins, 2013, 167). Banking performance is measured for the improvement and bank activities control to make banks more effective and more competitive to other banks.

This research uses ROA and Tobin's Q as a proxy of banking performance. ROA is a proxy from an accounting based perspective. ROA can measure overall profitability level (Kieso at al .: 700). Tobin's Q is a proxy from a market-based perspective. Tobin's Q can measure company value comprehensively. The value of Tobin's $\mathrm{Q}$ is measured through assets, liabilities, and equity. Tobin's $\mathrm{Q}$ is often used to examine the relationship between corporate governance and performance in 
companies and banks (Klapper and Love 2004, in Sudiyatno and Puspitasari, 2010 and Sari, 2010).

\section{Theoretical Framework and Hypothesis Development}

\subsection{Board size and board meeting relationship with banking performance}

Board of directors is a board responsible for overseeing the management of the company (FSB, 2013). Board responsibility is to oversee the risk management system and systems designed to ensure that the corporation obeys applicable laws, including tax, competition, labor, environmental, equal opportunity, health and safety laws. (OECD, 2015).

There are two types of board of directors structures. The first one is two-tier boards that separate the supervisory function and the management function into different bodies. Such systems typically have a supervisory board composed of nonexecutive board members and a management board consisting entirely of executives (OECD, 2015). This system is widely used in European countries such as Germany and the Netherlands. Indonesia is one of the countries that also use the two-tier system. The other one is unitary boards or one-tier boards, which bring together executive and non-executive board members (OECD, 2015). This system is used by some countries such as the United States, Australia, and Malaysia.

The number of the board of directors members in the bank may affect the effectiveness of bank performance. Some research examines the relationship between the board size or the number of boards of directors to performance, and the results vary. Dewayanto (2010) it is proved that there is a negative relationship between the board of directors size and the performance of banks. The results of his research considered the more board of directors, the more reduced the performance of banking. Meanwhile, according to Kusumawati and Riyanto (2005), the number of board of directors has a positive relationship with banking performance. The more the members of the board in the banking increasing the level of supervision, the more improve the 
banking performance will. Their results are supported by Binh and Tam (2014) research that found board size has a positive effect on banking performance.

Research suggests that there is a positive relationship between board size and banking performance. Following the perspective of agency theory, the board of directors can control the opportunistic behavior of management and can align the interests of shareholders and managers (Jensen 1993, in Kusumawati and Riyanto, 2005). Therefore, a growing number of board of directors will improve the supervisory function that encourages the improvement of banking performance. Also, according to signal theory, the increasing number of a director will be more comfortable in determining effective and efficient strategies to convey signals to external parties. This is due to the variation of the director's competencies and experiences.

Board of directors also has meetings regularly. Central banks in Indonesia and Malaysia have established a minimum of meetings to be held by boards. Bank Indonesia shall appoint a board of directors meeting at least 4 (four) times a year. Meanwhile, Bank Negara Malaysia sets the board meeting at least 1 (one) time every 2 (two) months. The number of meetings of the board of directors can be a measure of how effectively the board members perform their functions. The study of the relationship between the number of meetings held by the board and the performance of banking was conducted by Battaglia and Gallo (2015). They state that the variable number of board meetings negatively affects bank performance as measured by Tobin's q. Hadiprajitno's research (2013) found there is a positive relationship between the number of meetings and performance. This is caused by the idea that the more frequent the meetings are, the more the control of management quality will get affected.

Research suggests that a board meeting has a positive effect on banking performance. Following agency theory, the board of directors can align the shareholder and the management interests. The more frequent meetings conducted by the board will remove asymmetries between shareholders and management (Jensen 
1993, in Kusumawati and Riyanto, 2005). The frequency of more meetings will also give the board more time to make more effective decisions. This is slightly in line with the signal theory which states that the information will be a positive signal for external parties.

H1. Board size positively affects the performance of banks listed on the BEI and Bursa Malaysia.

H2. Board meeting positively affects the performance of banks listed on the BEI and Bursa Malaysia.

\subsection{Risk committee size and risk committee meeting relationship with banking performance}

The risk committee focuses on the implementation of the risk management framework. The member of this committee should have the necessary knowledge and experience to provide effective oversight of banking risks (BCBS, 2015). A risk committee can also provide greater support for company executives who are given broad risk management responsibilities, resulting in a stronger focus at the board level on the adequacy of resources allocated to risk management (Tonello, 2012). The risk committee also held a meeting to discuss the activities. Meetings are conducted following the needs of banks. Bank Indonesia and Bank Negara Malaysia as central banks have not issued regulations on minimum meetings to be held by the risk committee.

Battaglia and Gallo (2015) examined the risk committee size and risk committee meeting as a proxy for risk governance. The test results prove that there is a positive relationship between risk committee size and ROA and negative relationship with Tobin's q. This suggests that banks with larger risk committees have better profitability values. But the expected market assessment (Tobin's Q) in the bank is more extensive with a smaller risk committee size. They also found a positive relationship between the risk committee meeting and the performance measured by 
Tobin's q which means the value of the firm will increase with the high number of risk committee meeting.

This research will take the hypothesis with a positive relationship between risk committee size and risk committee meeting with banking performance. Agency theory states that agency problem arises because of the gap of interest between shareholders as the owner of the company with the management as an agent (Nuswandari, 2009). The managers tend to dislike risk or risk averse, while the shareholders want to get high returns following the statement of "high risk, high return". Therefore the behavior can be derived from applying the management supervision by the risk committee. The risk committee will also advise on risk appetite to management and provide reports to shareholders. Therefore, it will lower the adverse selection. Also, the risk committee will manage the bank risks so that the risk does not provide a negative signal to external parties.

H3. Risk committee size positively affects the performance of banks listed on the BEI and Bursa Malaysia.

H2. Risk committee meeting positively affects the performance of banks listed on the BEI and Bursa Malaysia.

\section{Research Method}

\subsection{Population, sample, and data collection method}

We use Indonesian and Malaysian banking data from 2010 to 2014 as samples. The samples are determined by using purposive sampling method. The criteria used to select the example are as follows:

1. Banks listed in Indonesia Stock Exchange and Bursa Malaysia.

2. Banks that published an annual report for period December 31, 2010-2014, at Indonesia Stock Exchange (IDX) and Bursa Malaysia.

3. Banks that disclosed information on ownership structure and financial ratios in its annual report. 
Data collection method used in this study are documentation and library methods obtained from libraries, Bank Indonesia website, official banking website, ASEAN official website, and the official website of Indonesia Stock Exchange and Bursa Malaysia.

\subsection{Variable and measurement}

Dependent variable used in this research is ROA and Tobin's Q as a proxy of banking performance. The independent variable used is the variable of risk governance. There are four independent variables: board size, board meeting, risk committee size, and risk committee meeting. Also, this research also uses the control variable in the form of bank size and CAR.

Table 2

Operational Variable

\begin{tabular}{|c|c|c|c|c|}
\hline \multicolumn{2}{|c|}{ Variable } & Definition & Measurement & Source \\
\hline \multicolumn{5}{|l|}{ Dependent } \\
\hline $\begin{array}{l}\text { Return on } \\
\text { Asset }\end{array}$ & ROA & $\begin{array}{l}\text { Comparison between profit } \\
\text { before tax and average total } \\
\text { assets in one period }\end{array}$ & $\begin{array}{l}\frac{\text { Earnings before tax }}{\mathrm{x} 100 \%} \\
\text { Average of } \\
\text { total assets }\end{array}$ & $\begin{array}{c}\text { Financial } \\
\text { Report }\end{array}$ \\
\hline Tobin’s Q & TQ & $\begin{array}{l}\text { The ratio of the firm's } \\
\text { market value to the cost of } \\
\text { asset replacement }\end{array}$ & 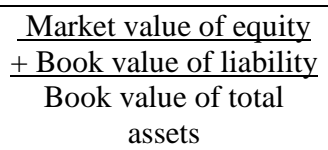 & $\begin{array}{l}\text { Financial } \\
\text { Report }\end{array}$ \\
\hline \multicolumn{5}{|l|}{ Independent } \\
\hline Board Size & BS & $\begin{array}{c}\text { Number of board members } \\
\text { at the bank }\end{array}$ & $\sum$ board members & $\begin{array}{l}\text { Annual } \\
\text { Report }\end{array}$ \\
\hline $\begin{array}{c}\text { Board } \\
\text { Meeting }\end{array}$ & BM & $\begin{array}{l}\text { Number of board meetings } \\
\text { per year }\end{array}$ & $\sum$ board meetings & $\begin{array}{l}\text { Annual } \\
\text { Report }\end{array}$ \\
\hline $\begin{array}{l}\text { Risk } \\
\text { Committee } \\
\text { Size } \\
\end{array}$ & RCS & $\begin{array}{l}\text { Number of risk committee } \\
\text { members at the bank }\end{array}$ & $\begin{array}{c}\text { Erisk committee } \\
\text { members }\end{array}$ & $\begin{array}{l}\text { Annual } \\
\text { Report }\end{array}$ \\
\hline $\begin{array}{c}\text { Risk } \\
\text { Committee } \\
\text { Meeting } \\
\end{array}$ & $\mathrm{RCM}$ & $\begin{array}{l}\text { Number of risk committee } \\
\text { meetings per year }\end{array}$ & $\begin{array}{c}\text { Erisk committee } \\
\text { meetings }\end{array}$ & $\begin{array}{l}\text { Annual } \\
\text { Report }\end{array}$ \\
\hline
\end{tabular}

\footnotetext{
${ }^{7}$ In this research, Indonesian bank uses some commissioner members as board size and Malaysian bank uses some board members as a board size.
} 


\begin{tabular}{|c|c|c|c|c|}
\hline \multicolumn{2}{|l|}{ Control } & Bank size & Ln(total asset) & $\begin{array}{c}\text { Financial } \\
\text { Report }\end{array}$ \\
\hline Bank Size & $\operatorname{lnSIZE}$ & Bank capital x & $100 \%$ & Financial \\
$\begin{array}{c}\text { Capital } \\
\text { Adequacy } \\
\text { Ratio }\end{array}$ & CAR & Capital Adequacy Ratio & ATMR & \\
\hline
\end{tabular}

Source: Bank Indonesia, Chung and Pruitt(1994)

\subsection{Econometric model}

The research method used in this research is quantitative. The technique used is multiple regression model, with the aim to know the relationship between a dependent variable with some independent variables. The basic model used in this research are as follows:

\section{Model 1}

$\mathrm{ROA}_{\mathrm{it}}=\alpha_{0}+\alpha_{1} \mathrm{BS}_{\mathrm{it}}+\alpha_{2} \mathrm{BM}_{\mathrm{it}}+\alpha_{3} \mathrm{RCS}_{\mathrm{it}}+\alpha_{4} \mathrm{RCM}_{\mathrm{it}}+\alpha_{5} \operatorname{lnSIZE_{it}}+\alpha_{6} \mathrm{CAR}_{\mathrm{it}}+\mathrm{e}_{\mathrm{it}}$

Model 2

$\mathrm{TQ}_{\mathrm{it}} \quad=\beta_{0}+\beta_{1} \mathrm{BS}_{\mathrm{it}}+\beta_{2} \mathrm{BM}_{\mathrm{it}}+\beta_{3} \mathrm{RCS}_{\mathrm{it}}+\beta_{4} \mathrm{RCM}_{\mathrm{it}}+\beta_{5} \operatorname{lnSIZE}_{\mathrm{it}}+\beta_{6} \mathrm{CAR}_{\mathrm{it}}+\mu_{\mathrm{it}}$

Remarks:

ROA = Return On Asset as a dependent variable

TQ = Tobin's Q as a dependent variable

$\alpha 0, \beta 0 \quad=$ constants

$\alpha 1-\alpha 6, \beta 1-\beta 6=$ regression coefficient

BS $=$ Board size as independent variable

$\mathrm{BM}=$ Board meeting as an independent variable

RCS = Risk committee size as independent variable

RCM = Risk committee meeting as an independent variable

$\operatorname{lnSIZE} \quad=$ Bank size as control variable

CAR = Capital adequacy ratio as a control variable

e, $\mu=$ error

i $\quad=$ cross section identifiers 
$\mathrm{t}=$ time series identifiers

This study uses sample banks in Indonesia and Malaysia separately so that there are four equations. Before performing hypothesis testing, we tested the classical assumption of multicollinearity test, heteroscedasticity test, and autocorrelation test. Multicollinearity test is done by looking at the results of the correlation test table on independent variables. If the value of the correlation between independent variables below 0.8 then the variable can be said free of multicollinearity. The heteroscedasticity test was performed by Park test. The autocorrelation test is done by looking at the Durbin-Watson value of the regression result. Regression result is done by using a fixed-effect model.

\section{Analysis and Results}

\subsection{Research samples}

Based on the criteria of sampling that have been described previously, the research samples are detailed as follows:

\section{Table 3}

Research Samples

\begin{tabular}{|c|c|c|c|lc|}
\hline No. & \multicolumn{1}{|c|}{ Bank Name } & Country & No. & Bank Name & Country \\
\hline 1 & Bank Capital Indonesia & Indonesia & 15 & $\begin{array}{l}\text { Bank Victoria } \\
\text { International }\end{array}$ & Indonesia \\
\hline 2 & Bank Bukopin & Indonesia & 16 & $\begin{array}{l}\text { Bank Artha Graha } \\
\text { International }\end{array}$ & Indonesia \\
\hline 3 & $\begin{array}{l}\text { Bank Negara Indonesia } \\
\text { (Persero) }\end{array}$ & Indonesia & 17 & $\begin{array}{l}\text { Bank Windu Kentjana } \\
\text { International }\end{array}$ & Indonesia \\
\hline 4 & $\begin{array}{l}\text { Bank Nusantara } \\
\text { Parahyangan }\end{array}$ & Indonesia & 18 & Bank Mega & Indonesia \\
\hline 5 & $\begin{array}{l}\text { Bank Rakyat Indonesia } \\
\text { (Persero) }\end{array}$ & Indonesia & 19 & Bank NISP OCBC & Indonesia \\
\hline 6 & Bank Danamon Indonesia & Indonesia & 20 & Bank Pan Indonesia & Indonesia \\
\hline 7 & Bank Pundi Indonesia & Indonesia & 21 & AMMB Holdings BHD & Malaysia \\
\hline 8 & Bank Jabar Banten & Indonesia & 22 & $\begin{array}{l}\text { CIMB Group Holdings } \\
\text { Berhad }\end{array}$ & Malaysia \\
\hline 9 & Bank QNB Indonesia & Indonesia & 23 & Hong Leong Bank BHD & Malaysia \\
\hline 10 & Bank Mandiri (Persero) & Indonesia & 24 & $\begin{array}{l}\text { K\&N Kenanga Holdings } \\
\text { Berhad }\end{array}$ & Malaysia \\
\hline
\end{tabular}




\begin{tabular}{|cll|clc|}
11 & Bank Bumi Arta & Indonesia & 25 & Malayan Banking BHD & Malaysia \\
\hline 12 & Bank Permata & Indonesia & 26 & RHB Capital BHD & Malaysia \\
\hline 13 & Bank Sinar Mas & Indonesia & 27 & Public Bank BHD & Malaysia \\
\cline { 1 - 2 } 14 & $\begin{array}{l}\text { Bank Tabungan Pensiunan } \\
\text { Nasional }\end{array}$ & Indonesia & & & \\
\cline { 1 - 2 } & & & & &
\end{tabular}

\subsection{Descriptive statistics}

The statistics table shows that the average ROA and Tobin's $q$ values in Indonesian and Malaysian samples are not much different. Meanwhile, the average value of board size in Malaysia is higher than Indonesia. This is due to differences in the organizational structure used in both countries. The minimum board meeting value in the sample of Indonesia is 3, which means that there are still banks in Indonesia who held meeting less than the provisions issued by Bank Indonesia, four times per year. Whereas in Malaysia the minimum board meeting value is 6 , means that all the banks have held board meetings following the provisions of Bank Negara Malaysia.

Furthermore, the average value of risk committee size and risk committee meeting on samples of Indonesia and Malaysia is not much different. For risk committee meeting value, neither Bank Indonesia nor Bank Negara Malaysia has issued a minimum requirement of the meeting. The value of lnSIZE in Malaysian sample shows a higher value from Indonesia, and this is because the average value of the asset in Malaysian bank is much bigger than Indonesia bank. CAR values in Indonesia and Malaysia samples are not much different.

\section{Table 4}

Descriptive Statistic

\begin{tabular}{|l|c|c|c|c|c|c|c|c|}
\hline & ROA & TQ & BS & BM & RCS & RCM & LNSIZE & CAR \\
\hline \multicolumn{8}{|c|}{ INDONESIA } \\
\hline Mean & 0,021 & 1,01 & 5,47 & 15,05 & 4,78 & 9,8 & 22,18 & 0,1676 \\
\hline Median & 0,0179 & 0,99 & 5 & 11 & 5 & 6 & 22,48 & 0,1649 \\
\hline Maximum & 0,0515 & 1,38 & 9 & 55 & 9 & 36 & 24,95 & 0,2929 \\
\hline Minimum & 0,0066 & 0,83 & 2 & 3 & 3 & 3 & 19,51 & 0,1167 \\
\hline
\end{tabular}


The Indonesian Journal of Accounting Research - May, Vol. 20, No.2, 2017

\begin{tabular}{|c|c|c|c|c|c|c|c|c|}
\hline Std. Dev. & 0,0112 & 0,11 & 1,99 & 13,59 & 1,7 & 8,21 & 1,59 & 0,0304 \\
\hline \multicolumn{9}{|c|}{ MALAYSIA } \\
\hline Mean & 0,0133 & 1,04 & 10,65 & 11,94 & 5,15 & 8,82 & 24,52 & 0,1672 \\
\hline Median & 0,0138 & 1,04 & 11 & 10 & 5 & 7 & 24,82 & 0,1465 \\
\hline Maximum & 0,025 & 1,39 & 14 & 21 & 10 & 25 & 25,93 & 0,419 \\
\hline Minimum & 0,0001 & 0,79 & 6 & 6 & 3 & 4 & 20,85 & 0,1046 \\
\hline Std. Dev. & 0,0059 & 0,13 & 1,76 & 3,84 & 2,12 & 5,01 & 1,34 & 0,0731 \\
\hline \multicolumn{9}{|l|}{ Notes: } \\
\hline \multicolumn{9}{|c|}{$\begin{array}{l}\mathrm{ROA}=\text { Return On Asset, } \mathrm{TQ}=\text { Tobin's } \mathrm{Q}, \mathrm{BS}=\text { Board size, } \mathrm{BM}=\text { Board meeting, } \mathrm{RCS}= \\
\text { Risk committee size, } \mathrm{RCM}=\text { Risk committee meeting, } \ln \mathrm{SIZE}=\mathrm{Bank} \text { size, } \mathrm{CAR}=\text { Capital } \\
\text { adequacy ratio. }\end{array}$} \\
\hline \multicolumn{9}{|c|}{$* * *$ Significant at $1 \%$} \\
\hline \multicolumn{9}{|c|}{$* *$ Significant at $5 \%$} \\
\hline \multicolumn{9}{|c|}{ *Significant at $10 \%$} \\
\hline
\end{tabular}

Source : processed data

Also, there is a correlation table between variables with bank sample in Indonesia and Malaysia. In general, board size, board meeting, risk committee size, risk committee meeting, bank size, and capital adequacy ratio are positively related to return on assets and Tobin's Q with sample banks in Indonesia. In the Malaysian bank sample, board size, board meeting, risk committee size, risk committee meeting, and bank size are also positively related to return on assets and Tobin's q.

Table 5

Correlation

\begin{tabular}{|c|c|c|c|c|c|c|c|c|}
\hline & ROA & TQ & BS & BM & RCS & RCM & LNSIZE & CAR \\
\hline \multicolumn{7}{|c|}{ INDONESIA } \\
\hline ROA & 1 & & & & & & & \\
\hline TQ & $0.5093^{*}$ & 1 & & & & & & \\
\hline BS & $0.4858^{*}$ & $0.2643^{*}$ & 1 & & & & & \\
\hline BM & $0.2948^{*}$ & 0.0458 & $0.2438^{*}$ & 1 & & & & \\
\hline RCS & $0.4103^{*}$ & $0.2251^{*}$ & $0.7352^{*}$ & 0.0653 & 1 & & & \\
\hline
\end{tabular}




\begin{tabular}{|c|c|c|c|c|c|c|c|c|}
\hline $\mathrm{RCM}$ & $0.3935^{*}$ & 0.0825 & $0.4428 *$ & $0.6917 *$ & 0.1459 & 1 & & \\
\hline LNSIZE & $0.6036^{*}$ & $0.3188^{*}$ & $0.7500^{*}$ & $0.3776^{*}$ & $0.6350 *$ & $0.4349 *$ & 1 & \\
\hline CAR & $0.1931 *$ & $0.1822 *$ & $-0,1452$ & $-0,1354$ & $-0,0697$ & $-0,0368$ & $-0,189$ & 1 \\
\hline \multicolumn{9}{|c|}{ MALAYSIA } \\
\hline ROA & 1 & & & & & & & \\
\hline TQ & $0.6227 *$ & 1 & & & & & & \\
\hline $\mathrm{BS}$ & 0.0535 & $-0,0926$ & 1 & & & & & \\
\hline BM & $0.5597^{*}$ & $0.5797 *$ & $\stackrel{-}{0,4034 *}$ & 1 & & & & \\
\hline RCS & 0.1688 & $0.4399 *$ & $\begin{array}{c}- \\
0,3845^{*}\end{array}$ & 0.2246 & 1 & & & \\
\hline $\mathrm{RCM}$ & 0.1147 & 0.1343 & $\begin{array}{c}- \\
0,7001 *\end{array}$ & $0.6651 *$ & 0.0653 & 1 & & \\
\hline LNSIZE & $0.7814 *$ & $0.5629 *$ & $-0,1581$ & $0.3911 *$ & $0.3830 *$ & 0.1394 & 1 & \\
\hline CAR & $-0,607 *$ & $\begin{array}{c}- \\
0,4106^{*}\end{array}$ & 0,277 & $-0,2728$ & $\begin{array}{c}- \\
0,3353 *\end{array}$ & $-0,1834$ & $-0,8862 *$ & 1 \\
\hline \multicolumn{9}{|l|}{ Notes: } \\
\hline \multicolumn{9}{|c|}{$\begin{array}{l}\mathrm{ROA}=\text { Return On Asset, } \mathrm{TQ}=\text { Tobin's } \mathrm{Q}, \mathrm{BS}=\mathrm{Board} \text { size, } \mathrm{BM}=\text { Board meeting, } \mathrm{RCS}= \\
\text { Risk committee size, } \mathrm{RCM}=\text { Risk committee meeting, } \operatorname{lnSIZE}=\mathrm{Bank} \text { size, } \mathrm{CAR}=\mathrm{Capital} \\
\text { adequacy ratio. }\end{array}$} \\
\hline \multicolumn{9}{|c|}{$* * *$ Significant at $1 \%$} \\
\hline \multicolumn{9}{|c|}{$* *$ Significant at $5 \%$} \\
\hline \multicolumn{9}{|c|}{ *Significant at $10 \%$} \\
\hline
\end{tabular}

Source : processed data

\section{Results}

The test results show that the independent variables in the equation have met the non-multicollinearity requirements. The correlation value between independent variables indicates this is below 0.8. Multicollinearity test results of independent variables can be seen in table 5 previous correlation. This study also used Park's test to find out whether or not heteroscedasticity in regression results. Park test with bank samples in Indonesia and Malaysia show that there was heteroscedasticity. This is eliminated by applying the white-heteroscedasticity test. This study uses the DurbinWatson test as a way to detect autocorrelation. Regression equation results passed the 
autocorrelation test if the value of DW-stat is between the value 1.54-2.46. The result of autocorrelation test on regression result of equation 2 with a sample of bank Indonesia and equation 1 with sample bank in Malaysia which indicate the problem of autocorrelation, therefore repaired by using AR (1) in regression.

The following table is the regression results of the four equations using the fixed effect model. From the regression results in the first model with the Indonesian bank, samples show the adjusted R-squared value of 0.8834 . From the regression results in the second model with the Indonesian bank, samples show the adjusted R-squared value of 0.7830 . Furthermore, from the regression results in the first model with Malaysian bank samples shows an adjusted R-squared of 0.9091. The regression results in the second model with Malaysian bank samples shows an adjusted Rsquared value of 0.5340 . The four models have an F-statistic probability value less than 0.05 which means that the independent variable can explain the dependent variable significantly.

Table 6

Regression Results

\begin{tabular}{|c|c|c|c|c|}
\hline \multirow{2}{*}{$\begin{array}{c}\text { Independent } \\
\text { Variable }\end{array}$} & \multicolumn{2}{|c|}{ INDONESIA } & \multicolumn{2}{c|}{ MALAYSIA } \\
\cline { 2 - 5 } & -0.065475 & $-4,49526$ & 0.425511 & $-1,91323$ \\
\hline $\mathrm{C}$ & $0.000913 * * *$ & 0.011458 & 0.000314 & -0.008275 \\
\hline $\mathrm{BS}$ & $0.000144 * *$ & 0.002854 & $0.000483 * * *$ & 0.016763 \\
\hline $\mathrm{BM}$ & $0.001728 * * *$ & 0.003109 & -0.000358 & $0.036898 * * *$ \\
\hline $\mathrm{RCS}$ & $0.000116 *$ & $-0.002249 * *$ & $0.000165 *$ & 0.000745 \\
\hline RCM & & & & 0.108818 \\
\hline $\ln$ & 0.003272 & $0.240488^{* * * *}$ & $-0.016947 * * *$ & \\
\hline
\end{tabular}




\begin{tabular}{|c|c|c|c|c|}
\hline CAR & -0.015636 & $0.416417 *$ & -0.006563 & -0.163656 \\
\hline DW - stat & 1,95703 & 2,315871 & 1,758701 & 1,852031 \\
\hline \multicolumn{5}{|l|}{ Notes } \\
\hline \multicolumn{5}{|c|}{$\begin{array}{l}\mathrm{ROA}=\text { Return On Asset, } \mathrm{TQ}=\text { Tobin's } \mathrm{Q}, \mathrm{BS}=\mathrm{Board} \text { size, } \mathrm{BM}=\text { Board meeting, } \mathrm{RCS}= \\
\text { Risk committee size, } \mathrm{RCM}=\text { Risk committee meeting, } \operatorname{lnSIZE}=\text { Bank size, } \mathrm{CAR}=\text { Capital } \\
\text { adequacy ratio. }\end{array}$} \\
\hline \multicolumn{5}{|c|}{$* * *$ Significant at $1 \%$} \\
\hline \multicolumn{5}{|c|}{$* *$ Significant at $5 \%$} \\
\hline \multicolumn{5}{|c|}{ *Significant at $10 \%$} \\
\hline
\end{tabular}

Source : processed data

The results of this study found that the performance of Indonesian banks as measured by return on assets is not only influenced by corporate governance variables but also risk governance variables, particularly risk committee size and risk committee meeting. The increasing number of risk committees and risk committee meetings will further increase the level of profitability in Indonesian banks. These results support previous studies of Battaglia and Gallo (2015) and support FSB recommendations (2013) on improving the risk governance framework. Specific risk monitoring should be done to prevent risks that may occur in bank activities. If such risks can be avoided, then it would be able to execute operational activities at the bank.

However, the results of this study indicate that the performance of Indonesian banks as measured by Tobin's $\mathrm{q}$ is only influenced by the risk governance variables, which is the number of risk committee meetings. There is a negative relationship between Tobin's q with the number of risk committee meetings. The more meetings conducted by the directors will get the stock market price of Indonesian bank lower. The frequent risk committee meeting has resulted in ineffective results, thus lowering the bank's stock price. 
The implication of this research is to improve supervision and risk governance framework that will enhance banking performance. Regulators may use the results of this study to emphasize the realization of risk governance to banks as recommended by the FSB and BCBS. Also, the results of this study can provide evidence to the academics that risk governance has a significant positive effect on return on assets in 2010 to 2014 period. The results can be considered to do the next research.

The result of the research with Malaysian bank samples proves that the performance as measured by return on assets is only influenced by the number of directors and risk committee meetings variables. The results show the number of directors and risk committees meetings affect the return on assets positively. The high number of meetings will give effective decisions thus increase profitability. The number of board and risk committees members do not affect the return on assets.

The results of this research prove that the number of risk committees variable affects the bank performance as positively measured by Tobin's q. This supports the recommendations issued by the FSB (2013) on improving oversight and risk governance frameworks. The higher the number of risk committees, the higher the level of supervision by risk committees in preventing the risk of banking, thus increasing the stock market price of the bank.

\section{Conclusion, Limitation, and Conclusions}

\subsection{Conclusion}

The results show that the risk governance variables affect the performance of banks measured by return on assets. The increasing number of risk committees in Indonesian banks can increase certain risk control thus reduce the level of risk occurrence in banks. Following agency theory which states agency problem arises because of two different interests of both parties, this can be derived from the risk committee supervision. Also, the more meetings held by the risk committee, the more effective decision will be provided so that it increases the profitability in the bank. The results of this study support the recommendations issued by the FSB (2013) to improve the supervision of risk governance in banks. However, the results of this 
study also indicate that the increasing number of meetings conducted by the risk committee can reduce the value of the company. We suspect that the presence of risk committee meetings carried out a negative impression on market reaction. Investors may know the causes of meetings that were being held by risk committees.

The results also show that bank profitability in Malaysia as measured by return on assets is only influenced by the number of meetings conducted by boards and risk committees. More meetings by boards or risk committees will increase profitability in Malaysian banks. More time for discussion can yield more effective outcomes or decisions. The research's results also prove that the number of risk committees on Malaysian banks affect the value of the company. A high number of risk committees will increase the level of supervision by risk committees in preventing the risk of banking. Thus it is increasing the stock market price of the bank.

\subsection{Limitation and Suggestion}

\section{Limitation}

We deal with some limitations in this research. First, this research only uses a sample of banks listed on the Indonesia Stock Exchange and Bursa Malaysia. Second, the observation period of this 5-year research will limit the analysis of long-term performance. Third, the proxy used in this research is a return on assets (ROA) and Tobin's Q. The governance characteristics in this research are still limited to the board of directors and risk committees that focus on supervision activities.

\section{Suggestion}

Further research is expected to use research samples such as banking in Southeast Asia or others so that the results can be compared with various countries and can be generalized. Also, further research is also expected to use samples of other financial institutions. Second, new research is expected to employ more extended period so that the study can predict banking performance in the long-term. Third, further research is expected to use not only the proxy of ROA and Tobin's Q but also add other variables 
such as ROE, BOPO, P/E, and so forth. Further research is also expected to use more complete and specific governance proxy, such as the level of work experience of directors and risk committees so that the results can explain precisely what factors that can affect banking performance.

\section{References}

Aebi, V., Sabato, G., Schmid, M. 2012. Risk Management, Corporate Governance, and Bank Performance in the Financial Crisis, J. Banking, and Finance. 36: 3212-3226.

Bank Indonesia. Publikasi Direktori Perbankan Indonesia, from http://www.bi.go.id/id/publikasi/dpi/default.aspx

Bank Indonesia. 2009. January edition. Outlook Ekonomi Indonesia 2009 - 2014.

Bank Indonesia. 2010. Krisis Global dan Penyelamatan Sistem Perbankan Indonesia.

Bank Negara Malaysia. 2009. How Did the Recent Global Recession Affect the Malaysian Economy?

Basel Committee on Banking Supervision. 2006. Enhancing corporate governance for banking organizations.

Basel Committee on Banking Supervision. 2015. Corporate governance principles for banks.

Battaglia, Francesca., Gallo, Angela. 2015. Risk governance and Asian bank performance: An empirical investigation over the financial crisis. Science Direct.

Binh, Dao Thanh., Tam, Dao Minh. 2014. Corporate Governance and Bank Performance - An International comparison Vietnam and Malaysia, Social Science Research Network.

Bursa Efek Indonesia. Laporan Tahunan Perusahaan Tercatat, from http://www.idx.co.id/id$\underline{\mathrm{id} / \text { beranda/perusahaantercatat/laporankeuangandantahunan.aspx }}$

Bursa Malaysia. List of Companies in main market, from http://www.bursamalaysia.com/market/listed-companies/list-of-companies/main-market

Chia, Siow Yue. 2013. The ASEAN Economic Community: Progress, Challenges, and Prospects. ADBI Working Paper Series.

Chung, Kee H., Pruitt, Stephen W. 1994. A simple approximation of Tobin's q. Financial Management. Vol. 23 (3): 70-74. 
Dewayanto, Totok. 2010. Pengaruh Mekanisme Good Corporate Governance Terhadap Kinerja Perbankan Nasional. Universitas Diponegoro.

Financial Stability Board. 2013. Thematic Review on Risk Governance

Hadiprajitno, Paulus B. 2013. Struktur kepemilikan, mekanisme tata kelola perusahaan, dan biaya keagenan di Indonesia. Jurnal Akuntansi \& Auditing. Vol. 9, No. 2: 97 - 127.

Hendriksen, Eldon S., Van Breda, Michael F. 2002. Teori Akunting Buku Satu. Tangerang: Interaksara

International Risk Governance Council, 2015. What is risk governance?

Jensen, Michael C., Meckling, William H. 1976. Theory of the firm: Managerial behavior, agency costs, and ownership structure. J. Financial Economics. 3: 305-360.

Kieso et al. 2013. Financial Accounting IFRS Edition. United States: Wiley

Komite Nasional Kebijakan Governance. 2006. Pedoman Umum Good Corporate Governance Indonesia.

Kusumawati, Dwi Novi., Riyanto, Bambang. 2005. Corporate governance dan kinerja: analisis pengaruh compliance reporting dan struktur dewan terhadap kinerja. Simposium Nasional Akuntansi.

Laeven, L., Levine, R. 2009. Bank governance, regulation and risk taking. J. Financial Economics. 93: 259-275

Malaysiastock.biz. Finance Listed Companies, retrieved from http://www.malaysiastock.biz/Listed-Companies.aspx?type=C\&value=FINANCE

Nuswandari, Cahyani. 2009. Pengaruh corporate governance perception index terhadap kinerja perusahaan yang terdaftar di bursa efek jakarta. Jurnal Bisnis dan Ekonomi. Vol.16 (2): $70-84$.

Organisation for Economic Co-operation and Development. 2015. G20/OECD Principles of Corporate Governance

Retno M, Reny Dyah. 2012. Pengaruh good corporate governarnance dan pengungkapan corporate social responsibility terhadap nilai perusahaan.

Rose, Peter S., Hudgins, Sylvia C. 2013. Bank management and financial services. United States: McGraw Hill

Sari, Irmala. 2010. Pengaruh Mekanisme Good Corporate Governance Terhadap Kinerja Perbankan Nasional, Universitas Dipenogoro. 
Sudarsono, Heri. 2009. Dampak Krisis Keuangan Global terhadap Perbankan di Indonesia: Perbandingan antara Bank Konvensional dan Bank Syariah, Bank Indonesia.

Sudiyatno, Bambang., Puspitasari, Ellen. 2010. Tobin's Q dan Altman Z-score sebagai indikator pengukuran kinerja perusahaan. Kajian Akuntansi. Vol. 2 (1): 9-21.

Susilowati, Yeye., Turyanto, Tri. 2011. Reaksi signal rasio profitabilitas dan rasio solvabilitas terhadap return saham perusahaan. Dinamika Keuangan dan Perbankan. Hal: 17-37, 1979-4878.

Taswan. 2010. Manajemen Perbankan Konsep, Teknik dan Aplikasi. Yogyakarta: UPP STIM YKPN.

Tonello, Matteo. 2012. Should Your Board Have a Separate Risk Committee? Harvard Law School Forum

Windah, Gabriela Cynthia., Andono, Fidelis Arastyo. 2013. Pengaruh penerapan corporate governance terhadap kinerja keuangan perusahaan hasil survei the Indonesian Institute Perception Governance (IICG) periode 2008-2011. Jurnal ilmiah mahasiswa Universitas Surabaya, Vol. 2 (1). 